\title{
Stage II Ampulla of Vater Neuroendocrine Tumor AJCC v8
}

National Cancer Institute

\section{Source}

National Cancer Institute. Stage II Ampulla of Vater Neuroendocrine Tumor A/CC v8. NCI Thesaurus. Code C135083.

Stage II includes: (T2, NO, M0); (T3, NO, MO). T2: Tumor invading through the sphincter of Oddi into duodenal submucosa or muscularis propria, or measuring more than $1 \mathrm{~cm}$. T3: Tumor invading the pancreas or peripancreatic adipose tissue. N0: No regional lymph node metastasis. M0: No distant metastasis. (AJCC 8th ed.) 